\title{
Assessment of Tree Registration in Leyte and Biliran Islands
}

Emma M. Germano ${ }^{1}$, Emmanuel G. $\operatorname{Tan}^{2}$, Eduardo O. Mangaoang $^{3}$ and Edwin Cedamon ${ }^{3}$

\author{
${ }^{1}$ DENR, R-8, Sto. Nino Ext., Tacloban City, Leyte, the Philippines \\ ${ }^{2}$ Emmanuel Tan, Forester III, Community Environment and Natural \\ Resources Office (CENRO), Baybay, Leyte \\ ${ }^{3}$ College of Forestry and Natural Resources, Visayas State University, \\ Visca, Leyte, the Philippines
}

\begin{abstract}
Staff in six Community Environment and Natural Resources Offices (CENROs) four in Leyte Province, three in Southern Leyte Province and one in Biliran - were interviewed to establish baseline information on tree registration. In general, the rate of tree registration was found to be low, except in CENRO Maasin, where during 1997 to 2006 a total of 2799 tree farms were registered, covering an aggregate area of 2807 ha and with 1,292,495 trees registered. The highest number of tree farms registered in CENRO Maasin took place in 2004, when a total of 531 were registered, covering an area of 373 ha. Measures and strategies practiced by this CENRO to promote tree registration include: conducting an information, education and communication (IEC) campaign including distribution of extension materials; establishing a link between farmers and buyers in marketing products; and encouraging barangay officials to disseminate tree registration information. Factors leading to the low tree registration rate in Leyte and Biliran CENROs include: long distance between farms and CENR offices; weak tenure (farms under timberland status); inefficient processing of the registration documents; absence of the officer-in-charge of tree registration during farmer visits to Department of Environment and Natural Resources offices; land under common ownership; and farmers unaware about the tree registration process. Suggestions by respondents to improve tree registration include: regularly conducting IEC activities including distribution of extension material, supported by necessary funding; hiring of additional personnel for this purpose, to be assigned in every municipality; enhancing the timber market network; deputizing barangay officials as Environment and Natural Resources Officers (ENROs) to conduct tree inventory, authorized by municipal officials to collect Tree Inventory Certification.
\end{abstract}

Keywords: IEC campaign, timber marketing, secure legal rights 


\section{INTRODUCTION}

Previous research experience on Leyte Island has revealed an increasing interest by smallholders in tree farming. This increasing interest was brought about by strong collaborative efforts among government agencies and non-government organizations during an information and education campaign on upland rehabilitation and ecological restoration. The substantial number of existing plantations and smallholder tree farms that can be found in various parts of the provinces of Leyte, Southern Leyte and Biliran are examples of this scenario (Cedamon et al. 2005).

During the implementation of the current ACIAR project (ASEM/2003/052) entitled 'Enhancing Financial Returns to Smallholder Tree Farmers in the Philippines', a list of registered private plantations from various Community Environment and Natural Resources Offices in Leyte Island was obtained from the Department of Environment and Natural Resources (DENR). These data were used as a starting point for locating tree farmers who are the main target of the project as the co-operators. A complex set of government regulations exists for tree registration, described by Calub (2005), which are administered by the DENR. Examination of tree registration data revealed that there are major differences in the rate of registration between the CENROs of Palo, Maasin, Baybay and Albuera, with CENRO Maasin having the greatest number of registered tree farms and CENRO Baybay having the least (Cedamon et al. 2005). One of the research activities of the ACIAR tree farmer project has been to identify the reasons behind differences in the rates of tree registration and policy implementation between CENROs, and measures to improve tree registration processes that will promote greater uptake of tree farming on Leyte and Biliran Islands.

\section{RESEARCH METHOD}

All CENROs on Leyte and Biliran Islands were identified as subjects of the study. These are located in Palo, Baybay and Albuera in Leyte Province, San Juan and Maasin in Southern Leyte Province and Naval on Biliran. Seven officers-in-charge of tree registration (including one former tree registration officer-in-charge in CENRO Palo) and one CENR Officer in CENRO San Juan were interviewed, using an openended questionnaire. Questions were included about tree registration purposes, strategies, difficulties, landholder responses to the regulations, and potential measures to promote increased registration.

\section{RESEARCH FINDINGS}

\section{Purpose and Nature of Tree Registration}

To understand fully what tree registration is, all respondents were asked what the main purpose of implementing tree registration activity in their CENROs was. Three respondents stressed that tree registration was carried out for various purposes, including: compliance with DENR policies, including Departmental Administration Orders (e.g. DAO. 99-20) requiring inspection of tree plantations on alienable and disposable land (A \& D land); validation of maps and trees registered with the CENRO; 
estimation and monitoring the volume of harvestable timber within the jurisdiction of the CENRO; and identification of specific tree farmers and linking them to possible timber buyers (e.g. establishment of a network for timber marketing). Two respondents mentioned further valuable purposes of this implementation. These include making possible the recording of number of tree farms and area coverage, monitoring the development of tree farms and trees planted thereon, and documenting how responsive private individuals are towards the tree planting campaign of the DENR. These respondents also noted that tree registration makes it easier for tree farmers to apply for cutting of their harvestable planted trees and provides recognition of the right of the landowner, as well as identifying farmers for technical assistance (Table 1).

Table 1. Main purpose of tree registration

\begin{tabular}{ll}
\hline Purpose & Frequency \\
\hline $\begin{array}{l}\text { Compliance to DENR policies (e.g. DAO. 99-20) requiring tree } \\
\text { plantation with A\&D lands to be inspected with validated map and }\end{array}$ & 3 \\
registered at the CENRO & 3 \\
$\begin{array}{l}\text { To determine and update volume of harvestable timber within the } \\
\text { jurisdiction of the CENRO }\end{array}$ & 3 \\
$\begin{array}{l}\text { Identify specific tree farmers and link them to possible buyers of timber } \\
\text { (e.g. establishment of an internet website) }\end{array}$ & 2 \\
$\begin{array}{l}\text { To determine the number of trees planted } \\
\text { To record area planted to trees }\end{array}$ & 2 \\
$\begin{array}{l}\text { To determine trees harvested and marketed } \\
\text { Identify tree farmers who need DENR technical assistance on tree }\end{array}$ & 2 \\
improvement & 2 \\
$\begin{array}{l}\text { To determine the number of tree farmers } \\
\text { To provide legal recognition of farmers' tree plantations }\end{array}$ & 1 \\
$\begin{array}{l}\text { To have concrete data on trees planted on A and D land } \\
\text { Recognition of the right of the landowner }\end{array}$ & 1 \\
$\begin{array}{l}\text { Promote tree farming on private land, to the benefit of landowners } \\
\text { Document the responsiveness of private individuals to tree planting } \\
\text { campaigns }\end{array}$ & 1 \\
$\begin{array}{l}\text { To record the specific locations of tree plantation } \\
\text { To determine the number of established plantations }\end{array}$ & 1 \\
$\begin{array}{l}\text { To monitor development of tree farms and number of planted trees } \\
\text { For managing and issuing Self Monitoring Forms (SMFs) }\end{array}$ & 1 \\
\hline
\end{tabular}




\section{Tree Registration Implementation Strategies}

Each CENRO has its own way of implementing tree registration. Government policy specifies clearly that tree registration should be free. All respondents admitted that among the CENRO's activities, tree registration has not been given much attention. Due to their meagre budget, some CENR offices charge tree farmers for expenses of their staff for travelling to farms, conducting a tree inventory and mapping as required for tree registration (e.g. a charge for their meals and transport). One CENRO requires applicants for tree registration to pay 100 Philippines pesos $(\mathrm{PhP})$ for every application for a Certificate of Private Tree Plantation Ownership (CPTPO), regardless of the number of trees covered. ${ }^{1}$ A fee of PhP50 is also required for the issuance of the Self Monitoring Form (SMF) in the case of private tree plantation owners or buyers wishing to transport logs or lumber coming from the registered plantation.

\section{Recent Tree Registration Activity}

As of December 2006, a total of 3988 tree farms with 2,290,317 trees were registered in CENR Offices covering an area of 6320.67 ha. In terms of number of tree farms registered, Maasin ranks first followed by Baybay, Palo, San Juan, Albuera and then Naval. The average farm size is 1.69 ha (Table 2). Observations from Cedamon et al. (2005) on the secondary data regarding the list of registered tree farms revealed that the tree area reported was sometimes the total area of the farm on which the trees are planted. This situation is due to DENR Memorandum Circular (MC) No. 97-09 and DENR MC No. 99-22 which requires land titles or tax declarations from landowners who wish to register their trees with the CENRO. Cedamon et al. (2005) noted that the estimated plantation age ranges up to 50 years. He observed that the estimated year of establishment of the tree 'farm' is not identified for a particular species but rather is for the whole tree farm, i.e. including other species. Tree farms typically are planted with - or are growing with - a mixture of native and exotic species. It should also be noted that almost $10 \%$ of the registered farms do not have information on the year of establishment, area of planting and number of seedlings planted, even though a $100 \%$ inventory of trees is required for registration (Cedamon et al. 2005). These authors noted that the most common species planted or growing on these registered tree farms are gmelina (Gmelina arborea) and mahogany (Sweitenia $s p p$.). Trees which have been growing for more than 20 years are usually native tree species including narra (Pterocarpus indicus), bagalunga (Melia dubia), molave (Vitex parveflora), raintree (Samanea saman) and ipil-ipil (Leucaena leucocephala).

\footnotetext{
${ }^{1} \$ \mathrm{US} 1=\mathrm{PhP50}$ approximately.
} 
Table 2. Number of registered tree farms and trees, aggregate area and average area planted, from all CENROs on Leyte and Biliran Islands

\begin{tabular}{lccrc}
\hline CENRO & $\begin{array}{c}\text { Number of } \\
\text { registered } \\
\text { tree farms }\end{array}$ & $\begin{array}{c}\text { Number of trees } \\
\text { registered }\end{array}$ & Area (ha) & $\begin{array}{c}\text { Average } \\
\text { size of } \\
\text { farm (ha) }\end{array}$ \\
\hline CENRO Maasin & 2804 & $1,292,495$ & 2703.9 & 0.50 \\
CENRO Baybay & 287 & 125,499 & 1450.3 & 5.07 \\
CENRO Palo & 274 & 291,687 & 1232.2 & 4.50 \\
CENRO San Juan & 282 & 258,640 & 189.0 & 0.25 \\
CENRO Albuera & 207 & 176,283 & 367.6 & 1.78 \\
CENRO Naval & 134 & 145,713 & 93.2 & 1.00 \\
Total & 3988 & $2,290,317$ & 6320.7 & 1.69 \\
\hline
\end{tabular}

In general, the recorded number of tree farms registered is low except for CENRO Maasin which consistently had the most farms registered from 1997 to 2006, with 2799 tree farms covering an area of 2807 ha and with 1,292,495 registered trees. The highest annual number of tree farms registered in Maasin (531) was recorded for 2004, covering an area of 373.03 ha (Table 3).

Table 3. Total number and area of registered tree plantations in each CENRO in Leyte and Biliran in a 10-year period 1997-2006

\begin{tabular}{|c|c|c|c|c|c|c|c|c|c|c|c|c|}
\hline \multirow[t]{3}{*}{ Year } & \multicolumn{12}{|c|}{ CENRO } \\
\hline & \multicolumn{2}{|c|}{ Maasin } & \multicolumn{2}{|c|}{ Palo } & \multicolumn{2}{|c|}{ San Juan } & \multicolumn{2}{|c|}{ Albuera } & \multicolumn{2}{|c|}{ Baybay } & \multicolumn{2}{|c|}{ Naval } \\
\hline & No. & $\begin{array}{l}\text { Area } \\
\text { (ha) }\end{array}$ & No. & $\begin{array}{c}\text { Area } \\
\text { (ha) }\end{array}$ & No. & $\begin{array}{l}\text { Area } \\
\text { (ha) }\end{array}$ & No. & $\begin{array}{c}\text { Area } \\
\text { (ha) }\end{array}$ & No. & $\begin{array}{c}\text { Area } \\
\text { (ha) }\end{array}$ & No. & $\begin{array}{c}\text { Area } \\
\text { (ha) }\end{array}$ \\
\hline 1997 & 110 & 151.34 & 0 & 0 & 12 & 19.56 & 0 & 0 & 0 & 0 & 0 & 0 \\
\hline 1998 & 29 & 50.56 & 0 & 0 & 7 & 11.9 & 0 & 0 & 0 & 0 & 2 & 1.90 \\
\hline 1999 & 63 & 62.92 & 0 & 0 & 2 & 1.3 & 15 & 24.74 & 0 & 0 & 1 & 0.02 \\
\hline 2000 & 246 & 324.77 & 0 & 0 & 9 & 8.29 & 15 & 39.33 & 0 & 0 & 4 & 19.56 \\
\hline 2001 & 242 & 198.94 & 0 & 0 & 0 & 0 & 13 & 17.13 & 0 & 0 & 8 & 3.35 \\
\hline 2002 & 333 & 328.25 & 0 & 0 & 18 & 3.32 & 8 & 0 & 0 & 0 & 1 & 2.70 \\
\hline 2003 & 443 & 387.20 & 0 & 0 & 3 & 25.3 & 19 & 13.6 & 0 & 0 & 0 & 0 \\
\hline 2004 & 531 & 373.03 & 199 & 906.22 & 141 & 36.67 & 11 & 6.32 & 29 & 93.96 & 1 & 7.99 \\
\hline 2005 & 404 & 437.09 & 39 & 172.96 & 22 & 5.305 & 38 & 28.48 & 67 & 50.81 & 9 & 6.02 \\
\hline 2006 & 224 & 124.98 & 36 & 153 & 8 & 2.38 & 92 & 240 & 142 & 118.6 & 25 & 25.48 \\
\hline
\end{tabular}


In terms of area covered in 2004, CENRO Palo ranked first followed by CENRO Maasin. It can be noted in Table 3 that CENROs Palo and Baybay have no data for 1997 to 2003. No tree registration certificates were issues in CENRO Palo during that period, although some farmers filed applications for tree registration. CENRO Baybay was only created in 2004. Naval commenced accepting applications in 1998, up until 2002, and resumed its recording in 2004.

\section{Factors Affecting Tree Registration Rates}

Respondents stressed that the low registration rate was due to the lack of an information, education and communication (IEC) campaign about tree farm registration. Two respondents stressed that farmers have negative views on the cost of tree registration, and DENR officers are dependent on the farmers to register their farms at the office due lack of funds allocated for travel expenses. Reasons for low registration rates are presented in Table 4.

Table 4. Reasons for non-registration of tree farms

\begin{tabular}{lc}
\hline Reason & Frequency \\
\hline $\begin{array}{l}\text { No proper information or lack of IEC activity about tree farm } \\
\text { registration (TR) }\end{array}$ & 4 \\
Some farmers are not aware of TR & 2 \\
$\begin{array}{l}\text { Some farmers do not place any importance on TR } \\
\text { Lack of funds for travelling expenses or negative thinking about the } \\
\text { cost of TR }\end{array}$ & 2 \\
$\begin{array}{l}\text { DENR officers are dependent on farmers who are willing to come to } \\
\text { the office to register their farms due to no allotted budget for travel }\end{array}$ & 2 \\
Most farmers tend to register their plantation when they want to & 1 \\
harvest the trees & 1 \\
Ignorance of the necessities of tree registration and its importance & 1 \\
Some farmers still don't know how to register & 1 \\
Lack of supporting documents & 1 \\
Some farners not interested & 1 \\
Hassle in securing the required documents & \\
Some farmers ignore requests to register because of doubt and lack of & 1 \\
concern & 1 \\
Proximity of locations & 1 \\
Lack of manpower to do the work & 1 \\
\hline
\end{tabular}

\section{Reasons for Registration of Tree Farms}

Reasons given by CENR staff about why farmers registered their trees are reported in Table 5. No single reason was widely mentioned. The ease of harvesting and issuance of transport documents because no permit is required for cutting of trees if a 
CPTPO has been obtained, and because farmers want to harvest their trees, were the reasons mentioned by two respondents. One respondent said that farmers are forced to register especially during harvesting time in order to know the actual volume available in the plantation, and because DENR provides linkages to buyers and provides technical assistance.

Table 5. Reasons why farmers choose to register their plantations

\begin{tabular}{lc}
\hline Reason & Frequency \\
\hline Easy harvesting and issuance of transport documents & 2 \\
$\begin{array}{l}\text { No permit is required for cutting of trees with Certificate of Private Tree } \\
\text { Plantation Ownership (CPTPO) issued }\end{array}$ & 2 \\
Farmers want to harvest their trees & 2 \\
Forced to register especially during harvesting time & 1 \\
To enjoy privileges such as that no permit is then required and to be & 1 \\
exempted from paying forest charges as mandated in (DMC. 99-20) & 1 \\
To have knowledge of the actual volume available in the plantation & 1 \\
To have a legal document of plantation ownership & 1 \\
To have linkage to buyers & 1 \\
DENR helps in terms of technical assistance and exposing to market & \\
\hline
\end{tabular}

\section{Measures and Strategies to Promote Tree Registration}

CENROs were found to have adopted a variety of strategies to encourage farmers to register their trees. Maasin, being the leading CENRO in the implementation of tree registration, adopted the following measures: conducting an IEC campaign including distribution of extension materials; establishing links between farmers and buyers in marketing products; and encouraging barangay officials to disseminate tree registration information during the inspection period. All respondents said that the most common strategy that they adopted is the conducting of an IEC campaign on tree registration during People's Day or during 'Barangay Pulong-pulong' (community conference) wherein people were gathered in one place where DENR officers made presentations about DENR functions. Another strategy was the distribution of flyers, encouraging farmers to relay to other farmers information regarding tree registration. Some CENROs also adopt innovative strategies that encourage tree registration, including strengthening the collaboration with the Philippine National Police (PNP) in implementing forest protection and law enforcement and radio presentations (without payment required from the DENR) (Table 6). 
Table 6. Measures and strategies adopted by CENROs to promote tree registration

\begin{tabular}{lc}
\hline Measure & Frequency \\
\hline $\begin{array}{l}\text { Conduct IEC campaign on TR during People's Day or during } \\
\text { Barangay Pulong-pulong }\end{array}$ & 8 \\
$\begin{array}{l}\text { CENRO personnel to conduct inventory of their plantations so that } \\
\text { farmers may not have any difficulty in securing a permit }\end{array}$ & 1 \\
$\begin{array}{l}\text { Distribution of flyers } \\
\text { Requiring farmers to relay information on tree registration to other } \\
\text { farmers }\end{array}$ & 1 \\
$\begin{array}{l}\text { Establishing a close coordination with PNP and line agencies to ensure } \\
\text { enforcement of Presidential Decree } 705 \text { (Forestry Code of the }\end{array}$ & 1 \\
$\begin{array}{l}\text { Philippines) } \\
\text { Provide smallholders with the necessary documents for tree }\end{array}$ & 1 \\
registration, including land maps & 1 \\
$\begin{array}{l}\text { Seedlings dispersal } \\
\text { Timber buyers (e.g. PASAR company) demanded supporting documents } \\
\text { before cutting/buying the timber }\end{array}$ & 1 \\
$\begin{array}{l}\text { Radio guest appearances offered for free } \\
\text { Barangay officials encouraged by the officer-in-charge of tree } \\
\text { registration to disseminate information on TR }\end{array}$ & 1 \\
$\begin{array}{l}\text { CENRO to provide 'pro formas' of the required documents for easy } \\
\text { completion. }\end{array}$ & 1 \\
\hline
\end{tabular}

\section{Suggestions from the Respondents to Improve Tree Registration}

Almost all respondents admitted that there have been shortcomings in tree registration implementation. For them to become more efficient and effective, all respondents suggested conducting quarterly IEC activities including distribution of extension materials, supported by the necessary funding (Table 7). Other suggestions included:

- an enhanced timber market network - because marketing network in Leyte is weak;

- hiring of additional personnel for the tree registration to be assigned in every municipality - because DENR lacks manpower to carry out tree registration;

- barangay officials to be deputized to be Environment and Natural Resources Officers (ENROs) to conduct tree inventory and authorized by the Municipal Officials to collect certification and other fees for their operations - again due to lack of manpower in the CENR Office;

- encouragement to tree farmers and furniture makers to engage in tree plantation development - to have a continuous supply of timber, and in the case of furniture makers, for them to add value to the timber they produce; 
- carrying out inventories of all established tree plantations on private land to identify the number of tree planters - to have a complete data on tree farmers for closer monitoring during harvesting of planted trees; and

- encouraging banks or other financial institutions to accept tree plantations as collateral for loans for the tree farmers to acquire capital for their timber enterprise.

Table 7. Suggestions from the respondents to improve tree registration

\begin{tabular}{lc}
\hline Suggestion & Frequency \\
\hline $\begin{array}{l}\text { Regular conduct of IEC activities including distribution of } \\
\text { extension materials supported by necessary funding }\end{array}$ & 8 \\
$\begin{array}{l}\text { Enhance market network } \\
\text { Hiring of additional personnel for this purpose to be assigned in }\end{array}$ & 2 \\
every municipality & \\
$\begin{array}{l}\text { Deputizing of barangay officials as Environment and Natural } \\
\text { Resources Officers (ENROs) to conduct tree inventories, with }\end{array}$ & \\
$\begin{array}{l}\text { authorization from the Municipal Officials to collect } \\
\text { tax/certification and other fees for these activities }\end{array}$ & 1 \\
$\begin{array}{l}\text { Encouraging tree farmers to engage in tree plantation development } \\
\text { bearing in mind what is needed in the locality }\end{array}$ & 1 \\
$\begin{array}{l}\text { It is imperative to conduct an inventory of all established tree } \\
\text { plantations on private land to identify the number of tree planters }\end{array}$ & 1 \\
$\begin{array}{l}\text { There must be a bank or financial institutions that accept tree } \\
\text { plantation area as collateral for loans }\end{array}$ & 1 \\
\hline
\end{tabular}

\section{CONCLUDING COMMENTS}

The various implementation strategies for tree registration adopted by the Leyte and Biliran Island CENROs have made a noticeable difference to the number of registered tree farms as based on the data gathered from each CENRO. The absence of a list of unregistered tree farms makes it difficult to determine the rate of tree registration, which is a limitation of this study. The fact that CENRO Maasin consistently achieved high tree registration numbers from 1997 to 2006 reflects the fact that the officers-in-charge of tree registration were doing their best to encourage registration while implementing the regulations. There is potential for other CENROs in Leyte and Biliran to adopt Maasin's strategies in order to increase tree registration not only in Leyte and Biliran but also in the whole of Region 8 of the Philippines. The suggestions provided by the tree registration officers-in-charge and CENR Officers could be of great help to address Objective 1 of the ACIAR Tree Farm project, which is to 'assist DENR to overcome the policy implementation constraints to tree registration and $\log$ transport currently restricting access to markets'. The survey of tree registration OICs and CENROs identified various constraints on tree registration, and provided a number of useful suggestions for improving the rate of tree 
registration. This requires that tree registration be given greater priority and funding by the DENR management.

\section{REFERENCES}

CALUB, F.S. 2005. DENR rules and regulations governing timber and timber products planted on private land. Annals of Tropical Research. 27(1): 91-96.

CEDAMON, E., EMTAGE, N., SUH, J., HERBOHN, J. and E. MANGAOANG. 2005. Present tree planting activities in four rural communities in Leyte Province, the Philippines. Annals of Tropical Research Scientific Journal. 27(1): 19-34.

CEDAMON, E., BERNALDEZ, S. and J. BAYNES. 2005. Trials and tribulations in locating tree farmers and sites for research and extension activities. Proceedings from the ACIAR Project Planning Workshop. 15-17 February 2005, Ormoc City, the Philippines.

DENR MEMORANDUM CIRCULAR 99-20. 1999. Supplemental guidelines governing the registration, harvesting, transport and marketing of timber by-products coming from private plantation within private lands or tax declared alienable and disposable lands. DENR Central Office, Diliman, Quezon City. 